\title{
Tourist Satisfaction on Culinary and Urban Tour in Sempur Park
}

\author{
Meizar Rusli \\ Faculty of Tourism \\ Universitas Pancasila \\ Jakarta, Indonesia \\ meizarrusli@univpancasila.ac.id
}

\author{
Teguh Pujiwioto \\ STIAMI Institute \\ Jakarta, Indonesia
}

\begin{abstract}
Culinary And Urban Tour business competition cannot currently be executed only based on intuition and foresight but must go through good management and the right marketing techniques. The exact marketing techniques cannot work without good communication from the manager which will be delivered to the prospective tourists and travelers, because the quality and quantity as well as marketing is something that cannot be separated. The objective is an input Culinary and Urban Tour business development in Sempur Park. The technique used in this study is the observation, questionnaires, and documentation. The sampling technique in this research used purposive sampling and accidental sampling. This study uses Importance-Performance and Recreation Opportunity Spectrum (ROS) Analysis, in this technique the respondents were asked to rank various attributes or elements of the bid based on the degree of importance of each of these attributes. In relation with the high amount of visitors, this research is focusing on the tourists visit while they're in the Sempur Park Area. Outcome of this research is expected not only in the effort of preserving the quality of the Sempur Park environments, but also the satisfaction level of visitors. The finding of this study showed tourists had been satisfied with culinary travel in Sempur park area Bogor City with $\mathbf{8 5 . 0 5}$ percent satisfaction rate and showing that the physical parameters is the spectrum that have high chances to fix the Sempur Park are.
\end{abstract}

Keywords - Tourist, Satisfaction, Culinary, Sempur Park

\section{INTRODUCTION}

Bogor City is the one of favorite tourist destination where much favored by tourists both locals and foreigns, with various potential that can attract tourists as the natural beauty of the Bogor Botanical Garden, cultural uniqueness as many Sindang barang culturals village, and the begining of the development of artificial tourism is like water park. The tourism industry is one of the leading economic development in the Bogor city, and becoming the main revenue of Bogor City for covering the local revenue (PAD). The number of tourists in 2014 who came to the city of Bogor reached 4.857.950 travelers, certainly attracting a lot of both local and foreign investors to invest in the city of Bogor. Hospitality and other facilities such as artificial water park and Food and Beverages Indsutry.that is one of the service industry that plays an important role in the success of tourism, also hotel, water park and food and beverage businesses that competing to attract tourists in the Bogor City.

One of the tourist area is already well known in the city of Bogor is a Sempur Park Culinary Tourism area is located in the Babakan Subdistrict Central Bogor District. Culinary tourism in Sempur Park is just a beauty and confort culinary place for foods lovers who want to enjoy the relatively cooler air than Jakarta while enjoying the old building and the old trees of the past. Although impressed quite fancy,but the price is affordable, still average in the range of $\mathrm{Rp} 7,000$ to $\mathrm{Rp} 75,000$ per portion. Bogor City reached within an hour driving from Jakarta can be an alternative after Bandung (Santosa, 2010).

The implementation of communication strategies in marketing can attract consumers with a positive impact on the company as increasing the sales and creating a good perception for business managers in the area of Sempur Park (Sempur Park Area) Culinary through studying of culinary tourist tour satisfaction Sempur Park, Bogor, with considering when the obtaining results through Importance performance Analysis can improve the quality of existing performance and minimizing the problems or weaknesses that need to be improved so that the traveler satisfaction of the Sempur Park culinary and urban tour that can be met and how the tourist perception, local people, government and the private sector on the sempur travel area quality. The objective is a input Culinary And Urban Tour business development in Sempur Park.

\section{CUlinARY TOUR}

Culinary art is the art of learning about food and beverage and various kinds related to food and drink, ranging from the preparation, management, presentation and storage. While the culinary arts is the art of learning about the food and drink that has a specific characteristic of traditional dishes throughout the archipelago (Fadiati in Ariani, 1994: 5). Based on the above explanation, the limitations on the culinary arts is the art of learning about a variety of food and beverages and a variety of kinds relating to food and beverages. Includes preparation, management, presentation and storage that have specific characteristic, Parma (2012).From the culinary arts develops a trend that is prevalent in today is a culinary tour.Wolf in Suriani (2009) states that culinary tourism is not a luxurious and exclusive tour.Culinary tours is emphasis on experience 
rather than on luxury restaurants or completeness types of food and bevarage available.

The definition of food tourism by Hall in Arifianto (2010)as follows: tourist is as a main actor of culinary tour that making activity to consume food and drinks are part of the main travel experience (impulse appears on the needs of the experience / set) or simply the need for consumption of a product (encouragement appears on the basic needs as human / hunger or thirst). Selection of destinations and tourist activity is influenced by their interest in local food there.

Culinary tourism in service is inseparable from the existence of the bistro or a restaurant.Bistro or restaurant are the buildings or commercial buildings that are organized, which carry out the service properly to all its guests either eat or drink. There is a restaurants that is inside in hotel, office or factory, and many is standing alone outside the building, Marsum (2001)

According Marsum (2001) the purpose of operating the restaurant other than for profit, giving the guests satisfactory is a primary purpose of a restaurant operating. Within this business happened sort of barter between the buyer and the seller in this case between the product and services with money. This barter will not run smoothly if the service people will handle the Services are not carefully selected, well educated and well trained, communication ability and coordinated meticulously and prepared sincerity. The concept of the restaurant consists of five elements Hsu and Power in Parma (2012), as follows:

\section{a. Menu}

These elements concept includes a restaurant begins offering from one type of menu (entree), such as an ice cream restaurant, donuts restaurant, until the restaurant that offering a menu or a full meal consisting of an appetizer, soup, main course and dessert. $\mathrm{Y}$

\section{b. Food Production Strategies}

Some restaurants offer fast food dishes, such as fast hamburgers, frech fries, and sandwiches, while the other restaurant offers the food that require long and complicated processing service such as the type of the classics restaurant.

\section{c. Service (service)}

Various restaurant Services depend on the type of restaurant. There is a formal offering restaurant services or fancy, and there are simple offering services services such as a buffet service.

\section{d. The price (pricing)}

The varios prices offered by the restaurant. There are restaurants that offer cheap dishes, medium, and there are restaurants that offer expensive prices.

\section{e. Decoration or atmosphere (decor / ambience /environment)}

The wide Various decoration or the offering atmosphere by the restaurants, depending on the theme of the restaurant itself. There are atmosphere romantic offering restaurants, the relaxed atmosphere, luxurious atmosphere, or displaying the characteristics of a region or country atmosphere.

In this study, the purposed tourist was the visitors who enjoy the culinary and urban tour in Sempur park culinary area and the offering products are all things related to service such as food and beverages. There are several methods that can be used every company in measuring or monitoring their customer satisfaction, Tjiptono (2004), as follows:

a. The complaining and targeting system

Each company which oriented to customer needs providing to the widest possible opportunity for its customers to submit the suggestions, opinions, and their complaints. Media that can be used including the suggestions and complaints boxes, comment cards, providing a specific line phone and so on.

b. The customer satisfaction survey

Surveys can be done with a questionnaire, by post, telephone or personal interview. By the survey, the company will obtain responses and feedback directly from customers and it also gives a positive sign that companies pay attention to its customers. Satistaction measurement of customer by this method can be done in various ways, among others:

\section{1) Direct Reports}

A measurement made directly by the questions, such as the phrase "how satisfied are you with the restaurant services a or b, on the following scale: very satisfied, satisfied, dissatisfied, very dissatisfied.

\section{2) Derived Dissatisfaction}

Questions that intended regarding the two main things, that is the magnitude of customer expectations against certain attributes and the magnitude of the performance they feel.

3) The Problem Analysis

Customers who are used by the respondents were asked to reveal two main things. First, the problems they face related to the company's offering. Second, suggestions for improvement.

4) Importance Performance Analysis (Performance Analysis and Interests)

Company is asked me to rank various elements (attributes) from the offering based on the degree of importance of each of these elements. It also asked me to rank how well the company's performance in such of each element / attribute.

\section{5) Ghost Shopping}

Companies tell certain people at a particular company or his own company to act as buyers / company's product potential customers and competitors. That Ghost shooper will report its findings regarding to the strengths and weaknesses of the company's products and competitors.

6) Lost Customer Analysis

Companies try to contact customers who have stopped buying, which is expected is to obtain information about the cause of it. The obtaining information will be useful for companies in decision making. 
This study using Importance Performance Analysis by calculating the level of interest and the performance of the offering products and calculate the level of satisfaction with the CSI (Customer Satisfaction Index) is used to determine the level of tourist satisfaction Culinary Sempur park thoroughly by seeing the level of performance and the interests of products attributes / services offered. generally, when a CSI value above 50 percent can be said that tourists has been satisfied otherwise if CSI scores below 50 travelers has not been satisfied. CSI scores in this study were divided into four criteria are not satisfied until satisfied. These criterias follow the criteria modifications carried out by PT.Sucofindo criteria in doing customer satisfaction surveys (Wahyu. 2006).

Formula:

CSI (Customer Satisfaction Index) $=$

$\frac{(X) \text { Performance }}{\text { (Y) Importance }} 100 \%$

\section{RECREATION OPPORTUNITY SPECTRUM (ROS)}

A major factor in the ROS analysis is the recreation area condition parameter identification(setting). recreation area parameters condition is the overall condition of the recreational area including parameters for the physical, social and management as a whole. Physical parameters affect the type of tourist activities and ultimately determine the type of recreation that can be developed. ROS summarizes the diversity of various parameter conditions tourist areas by specific experience. The combination of these parameters form a spectrum that leads to a kind of type of recreation that can be developed for tourist areas. recreation area condition parameters (Recreation Setting Attribute) are presented in Table 1.

\section{TABLE I. RECREATION SETTING ATTRIBUTE}

\begin{tabular}{lll}
\hline \multicolumn{1}{c}{ Physical Attributes } & \multicolumn{1}{c}{ Social Attributes } & \multicolumn{1}{c}{ Managerial Attributes } \\
\hline -Natural resources & -Education and & -Recreational Facilities \\
(water / land) & workforce & and infrastructure \\
-Topography & - Demographics & -Transportasi And \\
-Climatology & - Perception of the & communication \\
- Disposal of waste & tourist area & -Policy management \\
and impact & -Issues and problems & -Tourism Conditions
\end{tabular}

Space is defined as a place for humans and other living beings to perform activities in order to establish a life in the world which covers an area of land, sea and air. In urban studies, urban space is classified into two forms namely public spaces and commercial space. By using the concept of System Theory, Chapin and Kaiser (1995) illustrates that the city is a system in which there are actors and subsystems that interact with one another, namely Activities system, land Development Systems and Environmental Systems.

\section{RESULT AND DISCUSSION}

Sempur Park area is one of the areas where still exist many buildings of historical relics and a representation of the landscape of colonial settlements in the city of Bogor. Its existence itself gets increasingly pressured by growing economic activity in the vicinity as well as physical development that does not support the survival of the character of settlements in this area. Bogor City's processing development is increasing and changing currently which so much fast and affecting to the buildings preservation, sites, and environmental heritage Hidayat (2009). Through the development of tourism in the Bogor city, expecting not only doing efforts to increase more tourist arrival, being together with city administration and city management always preserve the building.

\section{Culinary Travel Attractions (Attraction)}

Culinary Tourism tour Sempur park area is generally the restaurant or cafe shop restaurant-type also Brasserie where the place that the guests can get having lunch, dinner, and supper quickly with affordable prices. In general, these systems with American service which the quick service is the priority. A small restaurant is like Cafeteria or Café that promotes the sale of cakes, sandwiches, coffee and tea, the limitation food choices and not selling alcoholic beverages. Inn tavern is a restaurant with affordable price which is managed by individuals in the city outskirt. The atmosphere is created very cordially and friendly with the guests, while the cuisine is delicious. Based on interviews with five production supervisors and service from five sample locations (Warung Taman, Warung Gumbira, Apple Pie, Macaroni panggang and Soup buah Pak Ewok), an average rate of visits has recorded reaching 300 visitors on weekdays and can reach 3 times on holiday.

\section{Accessibility}

Accessibility in Sempur park area is linked by a Pajajaran Street, Salak street, Sempur street connection from the outside area access and the comprising inside area access are Pangarango street, Jalan Ciremai street, Sempur park street, Tangkuban Perahu street which connects this area from surrounding center activities. These streets become the main circulation which connect the area from the city center. Has a width of 6-7 meters as wide enough for a settlement, completed with a green lane street with 1.5-2 meters width and covering trees. Sempur park Culinary area has such the speciality that one of its is the strategic location, close to the Bogor city center and having the city public transportation route.

\section{Amenities}

The existence of support facilities in Sempur park culinary area (Sempur Park) Bogor city was very helpful for tourist activity in enjoying the area itself. There are lodgings, points of Automated Teller Machine or Automated Teller Machine (ATM), toilet, wide parking area location for several business places in a strategic location, although the results of the questionnaire found dissatisfaction in some locations where less parking because it is not in the strategic locations. 


\section{Importance-Performance Analysis}

The research result questionnaire which distributed by researcher related to 16 variable indicators from Sempur park culinary tourism tour area, Bogor shows the interest identification result rate (expectation)every attribute to the reaching average 3.64 (X) and the implementation identification (performance) every attribute with reaching average 4.28 (Y), while the more detailed discussion can be seen in the list 2 , which shows the 5 variable indicators gain quite satisfied achievements and 11 variable indicators gain satisfied achievement with the average satisfaction level getting satisfied. In the list 2 shows that the speed, accuracy, friendliness / cleanliness and the image of the restaurant is on the quite satisfied achievement. Management can improve the quality at the five points in order to achieve satisfied predicate for all variables which will be achieved. Figure 1 Cartesian diagram that describes the strategy to improve the quality of performance based on the importance level

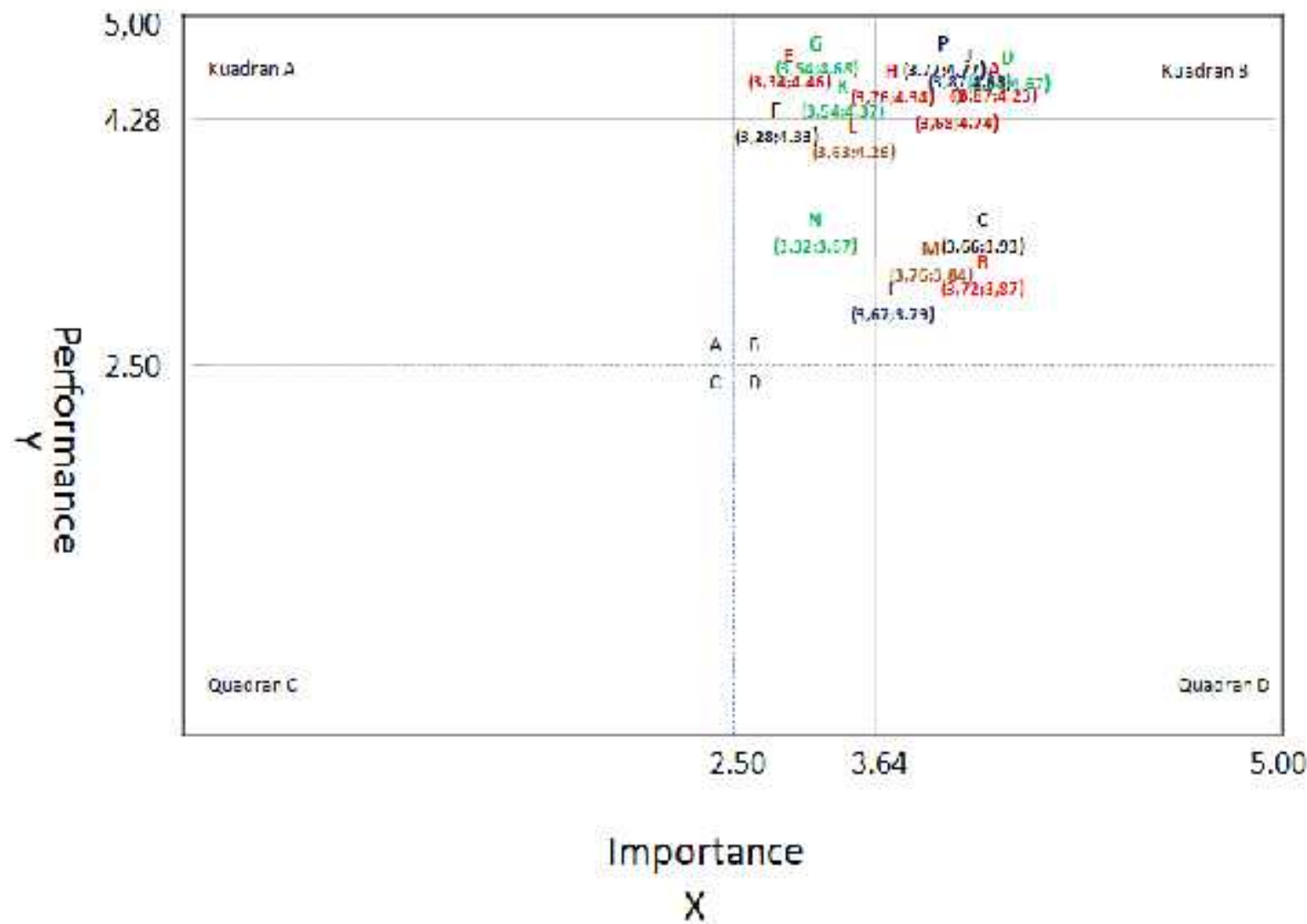

Fig. 1. Distribution of Cartesian diagram (Importance Performance Analisys) Source: Research Findings, 2016

Description Cartesian diagram:
A. Variety Type Food / Beverages
B. Concept / Menu Dishes characters
C. Local menu/ National / International
D. Availability of type dish / Ready Stock
E. Speed / Dishes accuracy
F. Fast dish / Fast food
G. dish accuracy / Art of Cooking
H. Simple Healthy
I. luxury Healthy
J. Home Atmosphere / relax
K. Service Atmosphere and king
L. Cheap Price
M. Strategic Location
N. Information and service before visit
O. Restaurants image
P. Service (friendly / Quick / clean)

\section{A Quadrant}

The attributes which contained in A quadrant has a high interest level according to tourists in Sempur park, but the performance is still low that effect attributes which contained in this quadrant should be prioritized for repairing. The attributes which contained in this quadrant includes e.speed /dish Accuracy f.fast dish / fast food g.dish accuracy / Art Cooking, k.service atmosphere and King. All these four variable indicators showed travelers expectations related to the maximum service from culinary service business tours, tourists assess the fulfillment of the speed and accuracy in service providing which becomes a culinary success barometer in the Sempur park area, because according to the characteristics of the type of restaurant in the area of Sempur park, generally offers the services of American service which prioritize the speed in the service. 


\section{B Quadrant}

The attributes which contained in the B quadrant have a high level of importance and performance is also assessed well by Sempur park tourist. The attributes which contained in this quadrant is a strength or management excellence in the tourists perception. Culinary travel services business management needs to maintain the quality and maintain the performance of these attributes. The attributes which contained in this quadrant includes d.Ketersedian type dish availibility / Ready Stock h.Simple j. Home atmosphere/ relax o.reataurant image p.service (friendly/ Fast / Clean). An analysis result of this attribute indicates the perception of the tourists for culinary service business tours in Sempur park area that generally goes well, take a look at an important component or specific in culinary services seemed good enough and proper to maintain as the availability of types of dishes, atmosphere, image and friendly service, as every guest or tourist who comes to feel the attributes which countained in the B quadrant which have achieved what they wanted in enjoying the culinary products in Sempur park area, Bogor.

\section{Quadrant}

The attributes which contained in the $\mathrm{C}$ quadrant have a low interest level and not good performance management perseption by travelers. The management itself needs to improve its performance against these attributes in it to prevent these attributes shift to quadrant $\mathrm{A}$. The attributes which contained in this quadrant among others

1.cheap price and n.Information and services before the visitation $t$. Based on observations result, questionnaires and interviews, tourists are generally not concerned regarding the price because they thought that had been equal with what they obtained. Management must remain sharp in deciding for the everyprice menu with business competition consideration and social media promotion quality improvement that will make campaign more familiar to the tourists about culinary products offered before, during and after enjoying a visit.

\section{Quadrant}

The attributes which contained in D quadrant have a lower interest level according to respondents but has performed well so considered excessive by the respondent. performance improvementon in these attributes would only lead to waste of resources. The attributes which contained in this quadrant,those are a.various type of Food / Beverage b.Koncept / Dishes menu characters c.local Menu / National / Internationally.fancy Healthy m. Strategic location. Because attributes such as strategic location, generally Sempur park culinary travel area is located in a strategic location, but when we speak about every restaurant location or cafe there are some differences related to the location. The location other than the impact on the ease of achievements and a convenient parking area,the tourist assess for the large parking can mprove the rating of service quality in Sempur park tourism area, Bogor, especially when the holiday. The menu which offered is considered good enough by tourists, both in variety, character and health of the menu.

Importance and performance analysis results in Figure 1 assuming the value of the center $\mathrm{X}=2.50$ and $\mathrm{Y}=2.50$ was found that the overall value of $X=3.64$ and $Y 4: 28$ fall in the B quadrant point where that point is considered good and proper maintain. Overall rating assessed by tourist that culinary products offered by Sempur park management which it had been good appropriately both in the menu, the strategy of production, service, price and atmosphere.

TABLE II. CALCULATION SATISFACTION RATING

\begin{tabular}{lll}
\hline \multicolumn{1}{c}{ Variable Indicators } & CSI / Satisfaction (\%) & \multicolumn{1}{c}{ Indicator Level of Satisfaction } \\
\hline Type of Food / Beverage & 91,48 & Satisfied \\
Concept / Characters Menu & 96,12 & Satisfied \\
Menu Local / National / International & 93,12 & Satisfied \\
Availability of type dish / Ready Stock & 81,79 & Satisfied \\
Accuracy Dishes & 74,88 & Quite Satisfied \\
Speed Dishes & 75,75 & Quite Satisfied \\
Art of Cooking & 75,64 & Quite Satisfied \\
Simple \& Healthy & 86,63 & Satisfied \\
Luxury \& Healthy & 96,83 & Satisfied \\
Atmosphere of Home & 82,69 & Satisfied \\
Atmosphere of Service & 81,00 & Satisfied \\
Cheap price & 85,21 & Satisfied \\
Strategic location & 97,91 & Satisfied \\
Information and service before visit & 90,46 & Satisfied \\
Brand & 77,63 & Quite Satisfied \\
Services & 79,03 & Quite Satisfied \\
\hline Average & $\mathbf{8 5 , 0 5}$ & Satisfied \\
\hline
\end{tabular}

At 2 shows that in accordance with culinary travel management elements: 1. Menu (various types, concepts and availability of local and international menu) because travelers assume that a various menu including local and international have been offered in accordance with the satisfaction level reached above 90 percent. 2. Production Strategy and Services (accuracy, fast dish, simple, fancy, information, friendly, clean) which these elements have been fulfilled, the attribute is still below 80 percent, because the tourist assume the speed and accuracy with very high important value with the below average performance.3. Price and Environment atmosphere, based on the calculation of the tourist satisfaction level obtaining the proper price corresponding to environment atmosphere with the offering concept so expectations before the visit have been met. 
Space is defined as a place for humans and other living beings to perform activities in order to establish a life in the world which covers an area of land, sea and air. In urban studies, urban space is classified into two forms namely public spaces and commercial space. By using the concept of System Theory, Chapin and Kaiser (1995) illustrates that the city is a system in which there are actors and subsystems that interact with one another, namely Activities system, land Development Systems and Environmental Systems.

\section{Analysis of Recreation Opportunity Spectrum}

In an effort to determine the spectrum of tourism opportunities in the development and Sempur areas tourism management, then doing the area condition analysis which is outlined in the form of a matrix. The matrix outlines the condition of each parameters which then called by the Recreation Setting Atrribute as presented in Table 3

\section{TABLE III. RECREATION SETTING ATRRIBUTE}

\begin{tabular}{|c|c|c|c|c|}
\hline No & Parameter & Weights & Score & WX S \\
\hline \multirow[t]{7}{*}{1} & Physical Attributes & & & \\
\hline & Carrying & 0.5 & 3 & 1.5 \\
\hline & Cleanliness & 0.5 & 2 & 1.0 \\
\hline & Leisure & 0.5 & 2 & 1.0 \\
\hline & Coolness & 0.5 & 2 & 1.0 \\
\hline & Total & & & 4.5 \\
\hline & Average & & & 1.3 \\
\hline \multirow[t]{7}{*}{2} & Managerial Attributes & & & \\
\hline & Facility & 0.3 & 2 & 0.6 \\
\hline & Transportation & 0.3 & 3 & 0.9 \\
\hline & Communications & 0.3 & 3 & 0.9 \\
\hline & Waste Management & 0.3 & 1 & 0.3 \\
\hline & Total & & & 2.7 \\
\hline & Average & & & 0.7 \\
\hline \multirow[t]{5}{*}{3} & Social Attributes & & & \\
\hline & Education and workforce & 0.2 & 2 & 0.4 \\
\hline & Perception of the sempur area & 0.2 & 2 & 0.4 \\
\hline & Total & & & 0.8 \\
\hline & Average & & & 0.4 \\
\hline
\end{tabular}

The 3rd main parameters results showed that the physical is parameter that have the highest value. Showing that the physical parameters is the spectrum that have high chances to fix the sempur garden area. Associated with the other two spectrum at the level of management, waste management should be a priority reform that must be done.

\section{CONCLUSION}

Based on the analysis and study that has been stated, and then as the conclusion of a study that has been done indicated that the Sempur park culinary tour area has good potential as a culinary tourism destination. This includes the quality and quantity of various attractions, the service mechanism on the culinary tour business services adapted to the characteristics specified in the theme that is American service (fast food), affordable price and the peculiarities decoration. Support amenitas such as the exist lodging, parking lot, Automated Teller Machine (ATM) and toilet. The strategic location also eases traveler's accessibility to access the area. Through Importance-Performance Analysis approach in measuring satisfaction, tourists had been satisfied with culinary travel in Sempur park area Bogor City with 85.05 percent satisfaction rate. Reforming priorities are such as the attributes of speed /dish accuracy, fast dish/ fast food, cooking art accuracy, full service atmosphere. Quality that can be maintained that is the availability of the type of dish, healthy simple, home atmosphere / relax, the restaurant image and service (friendly / fast / clean). Recommendation to the Bogor city administration can be more assertive in maintaining the quality for Sempur Park area such as the security, cleanliness and arrangement of the spreading street vendors at some points so that unfavorable conditions can be minimized. To the service business management should be able to improve the speed and accuracy of the dish by the human resource needs evaluation $\mathrm{n}$ (HR) / employees as well as conducting improvement trainings of services for the entire HR / employee to achieve quality of service so that tourist satisfaction can be achieved. Sempur park area Culinary service Business leadership management area Bogor is required to remain consistent, with the availability of dishes, healthy simple, the teataurant image and service (friendly / fast / clean) that has been done so far, creating new breakthrough in promotion matter, expected can be better communication for the advantages of the product compared with other locations culinary and urban tour.

\section{REFERENCES}

Ariani, R.P. (1994), Bali Culinary Arts feasibility study About Bali Province Traditional Cuisine. Reportation Reaseach. Singaraja: STKIP.

Arifianto, Muhammad Yusuf. (2010), Culinary And Satisfaction Tour Presentation (Correlation Study Between Culinary Tour Presentation Watching Motivation On Trans Tv And Audience Satisfaction Amongst Amta Yogyakarta Academic Students Year 2008), Thesis, Surakarta: Faculty of Social and Political Sciences, Communications Study Program of Sebelas Maret University

Gede Parma, I Putu (2012), Strategy Development Formulation of Local Cuisine as Culinary Tourism Product in the Buleleng Regency, Thesis, Denpasar: Postgraduate Program of Udayana University.

Hidayat, R. (2009). The Bogor City Cultural Heritage Preservation Bylaw Local Regulation Prepared.Online accessed June 29, 2015 at 18:00 pm, received from http://kompas.com.

Kaiser, Edward, J, Godschalk, David, R, and Chapin, F. Struart Jr. (1995). Urban Land Use Planning, 4th Edition, The Board of Trusees of Univ. Illinois, USA.

Marsum, WA. (2001). Restaurants and Everything problem. Yogyakarta: Publisher Andi.

Rahmawati, Ani. (2009). Study of Coastal Zone Management for Coastal Tourism Activity (Case Teleng Ria Beach Pacitan Regency, East Java), Bogor: Bogor Botanical Institute.

Santosa, Iwan. (2010). Taman Kencana, Heaven Culinary.January 23,2010.Online: http://megapolitan.kompas.com/read/20 
10/01/23/04072194/Taman.Sempur..Surga.Kuliner. accessed May 13, 2015 at 7:05 pm.

Suriani, N. M. (2009). Culinary Arts Bali as One Travel Attractions Case Studies Warung Babi Guling Ibu Oka In the village of Ubud, Gianyar, Bali, Thesis, Denpasar: Master of Tourism Studies Udayana University.
Tjiptono, Fandy.(2004). Services Management, Yogyakarta: Publisher Andi.

Wahyu, Riandina and Rita Nurmalina. (2006). Analysis of Visitor Satisfaction and Tourism Facility Development of Agro Pasirmukti Tourism Gardens, Bogor, Agro Economic Journal IPB. 